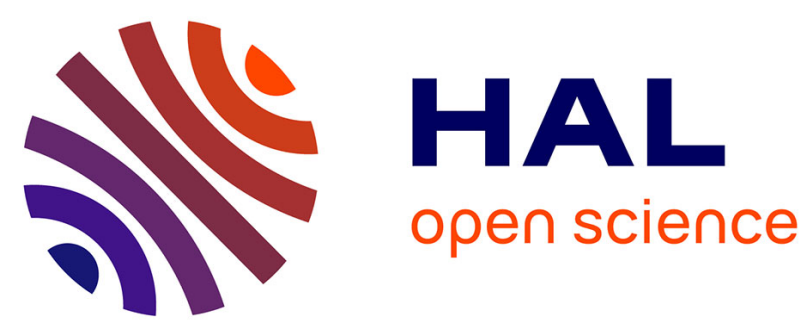

\title{
Causes of Delivery-Time Variance in Maritime-Equipment Manufacturing Supply-Chains: An Empirical Study
}

\author{
Olumide E. Oluyisola, Tuomo E. Salmi, Jan Ola Strandhagen
}

\section{To cite this version:}

Olumide E. Oluyisola, Tuomo E. Salmi, Jan Ola Strandhagen. Causes of Delivery-Time Variance in Maritime-Equipment Manufacturing Supply-Chains: An Empirical Study. IFIP International Conference on Advances in Production Management Systems (APMS), Aug 2018, Seoul, South Korea. pp.415-421, 10.1007/978-3-319-99704-9_51 . hal-02164914

\section{HAL Id: hal-02164914 \\ https://hal.inria.fr/hal-02164914}

Submitted on 25 Jun 2019

HAL is a multi-disciplinary open access archive for the deposit and dissemination of scientific research documents, whether they are published or not. The documents may come from teaching and research institutions in France or abroad, or from public or private research centers.
L'archive ouverte pluridisciplinaire HAL, est destinée au dépôt et à la diffusion de documents scientifiques de niveau recherche, publiés ou non, émanant des établissements d'enseignement et de recherche français ou étrangers, des laboratoires publics ou privés. 


\title{
Causes of delivery-time variance in maritime-equipment manufacturing supply-chains: an empirical study
}

\author{
Olumide E. Oluyisola, Tuomo E. Salmi, and Jan O. Strandhagen \\ NTNU - Norwegian University of Science and Technology, \\ Department of Mechanical and Industrial Engineering, Trondheim, Norway \\ olumide.e.oluyisola@ntnu.no; tesalmi@stud.ntnu.no; \\ ola.strandhagen@ntnu.no;
}

\begin{abstract}
The overall performance of manufacturing companies has become increasingly dependent on their ability to coordinate a network of suppliers effectively. For manufacturers of customized equipment, it is even more important to coordinate several such network relationships concurrently to achieve service level objectives while minimizing inventory- and quality-related costs. In this paper, we investigate the causes of delivery variance in an engineer-toorder supply chain. Using four case companies within the global supply chain of a customized maritime-equipment manufacturer, we discuss these causes of delivery-time variance and suggestions for managing them.
\end{abstract}

Keywords: performance management, supplier development, global manufacturing network.

\section{Introduction}

The overall performance of manufacturing companies - and especially, the 'on-time' delivery of products to customers - is increasingly dependent on their ability to coordinate a network of suppliers effectively. For manufacturers of customized equipment such as thruster systems used in large ships, purchased components and subassemblies can represent up to eighty percent of the total contract value [1, 2]. Hence, manufacturers of complex, customized-equipment (also referred to as engineer-toorder or ETO) often need to coordinate several such networks of suppliers concurrently to deliver products on time, at minimum cost and at the right quality [2]. Consequently, the delivery performance of suppliers plays a vital role in the overall delivery performance of ETO manufacturers [1, 2].

Supplier delivery performance is often measured using two performance indicators: delivery lead-time, which is an indication of how soon an order can be fulfilled; and delivery reliability, an indication of the variance or the deviation from the expected or promised 'delivery window' [3]. All deliveries outside the expected delivery window are considered as not being delivered on-time, since they always lead to additional costs [4] in the form inventory handling costs or disruptions to planned 
allocation of manufacturing resources. It could also be in the form of penalties from the end-customer for late order delivery.

This paper presents empirical findings [section 4] from an investigation of the causes of demand variance in a ship building supply chain. The study comprises four suppliers and a focal company, which manufactures several critical subsystems for ship builders in Asia and Europe. The management team of the focal company in this study identified long delivery lead-time and high delivery variability as key issues hampering the competitiveness of its Asian operations, which is the target of this study. Thus, this study was commissioned to investigate the factors affecting the delivery performance of the four tier-2 suppliers - tier-2 because the focal company is itself a 'tier-1' supplier for ship-builders. One important objective of the study, therefore, was to enable management adequately price the cost of this variance into supply chain transactions and to serve as a motivation for improvements by its members. To address this objective, we briefly considered the theoretical background [section 2] for supply performance in ETO supply chains. Thereafter, a description of the data collection methodology and a case description follows [section 3]. The findings are presented in a structured format [section 4], and discussed in final section.

\section{Theoretical background}

\subsection{Market and supply characteristics of ETO supply chains}

A central challenge in ETO markets is high demand fluctuation, which is generally higher than that witnessed in, say, mass production cases, and is almost impossible to forecast $[1,2,5]$. This condition creates a big challenge for manufacturers and at the same time, a business opportunity for companies that are able to deliver in short lead time and within the promised delivery window [6]. In addition to delivery performance, other sources of competitiveness are: design or engineering competences, price and responsiveness [1]. High degree of responsiveness is particularly important in the tendering phase. Caron and Fiore [7] and Gosling and Naim [8] have also identified flexibility in the order fulfillment process as a crucial for order-winning by ETO companies. Surveys [9] have further revealed that seventy percent of project-based cost overruns are due to delivery untimeliness, and that on-time delivery is a good indicator for projects that want to achieve minimize such costs.

Because of such demand characteristics, combined with the fact that each produced unit is a large proportion of the production capacity, a major source of risk for ETO companies is, therefore, that supplier relationships can vary significantly [1, 6]. One reason for this variation is the demand uncertainty, which limits cooperative longterm supply chain relations [1]. To cope with this uncertainty, a large portion of production is outsourced - sometimes up to eighty percent $[1,2]$. In order to reduce supply uncertainty many ETO companies use multi-sourcing [6] which is characterized by mutual mistrust and "win-lose" transactions [1]. Furthermore, ETO companies recognize that there are benefits in developing suppliers for long-term collaboration [1]. For those long-term collaborations, the delivery variance must be minimized or eradicated where possible. 


\subsection{Causes of delivery variance in supply chains}

The difficulty in controlling ETO delivery timeliness arises from the poor coordination of the interface between engineering and production, and especially in coordinating multiple organizations, not coordination in single organization [10]. Furthermore, the trend of outsourcing production to low-labour cost countries and retaining engineering as a core expertise has resulted in an even larger gap between engineering and production leading to more delays in delivery. Several other causes have been documented in the literature $[10,11]$ namely:

a. procurement phase delayed due to missing designs and poor quality of documentation;

b. high number of quality problems at the supplier; information flow not integrated between supplier and buyer;

c. poor visibility of business processes by decision makers and workers;

d. excessive optimism in business partner's skills;

e. poor delivery documentation;

f. long-lead times, which increases the chance of occurrence of unpredicted events (e.g. strikes, new trade regulations etc.); and

g. changes in technical requirements after production starts.

Some of causes originate from process and product uncertainty, while others originate from the people-related and organizational factors.

\subsection{Management of delivery variance in supply chains}

According to Guiffrida and Jaber [12], supply chain managers can use deliveryvariance reduction in order to improve delivery performance in a similar way that quality managers historically used the reduction of process variation to improve product quality. In their model, the delivery variance $(v)$ is traded-off against investment in continuous improvement of on-time delivery (cost). Defining the variables $\mathrm{G}(v)$, total cost supplier untimeliness; $\mathrm{Y}(v)$, the expected cost (penalty) of untimely delivery; $\mathrm{C}(v)$, investment cost for delivery variance reduction; and $v$, delivery variance, Guiffrida and Jaber [12] obtained the following:

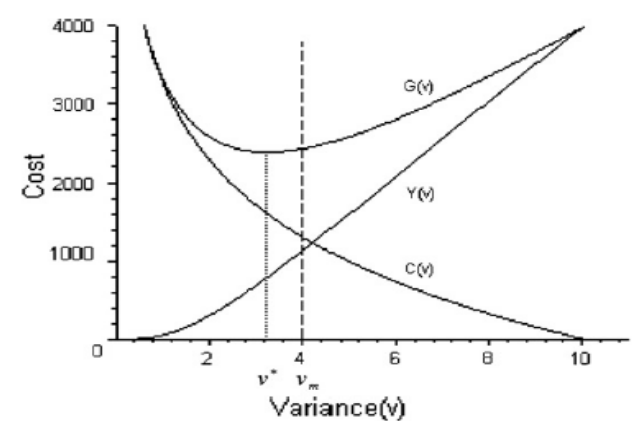

Figure 1: Optimal delivery variance model [12] 
The model suggests that there is a variance level, $v^{*}$, at which total cost of untimeliness is minimized. This indicates that a trade-off must be regarding (a) how much to invest in efforts to reduce the cost of untimely delivery and (b) how much penalty is expected due to untimely delivery. Several ways to control this variance have been reported namely: the supplier gaining tighter control over process flow times; enhanced coordination of freight transport; more efficient material handling of outbound stock by the supplier and inbound stock by the buyer; and improved communications between both parties $[12,13]$.

\section{$3 \quad$ Methodology and case description}

\subsection{Data collection method}

This paper uses a case study design with five units of analysis - the four tier-2 suppliers, serving a common customer which will be referred to as Company $\mathrm{S}$ - not real name. Company $\mathrm{S}$ is a customized-equipment manufacturer serving the ship building industry. Data is collected using semi-formal interviews based on an interview guide, in addition to factory tours at Company $\mathrm{S}$ and the four tier-2 suppliers. The interviews were conducted with the supply chain management staff of Company S by the second author using an interview guide, with follow-up phone calls and meetings with the four suppliers for clarification and verification.

The objective of the interview was to identify the critical processes and procedures that contribute to poor supplier delivery performance at the four tier-2 suppliers. The interview guide was designed to elicit the causes for poor delivery performance, the implications of poor supplier delivery performance, and the current supplier delivery performance practices. Followed-up meetings aimed to elicit managers' recommendations about how the delivery performance could be improved.

\subsection{Case selection and description}

The four suppliers operate in China and Europe, while Company S has its headquarters in Europe and a production subsidiary in China. Out of several suppliers, these four suppliers (of Company S) were selected based on following criteria:

a. The supplier has underperformed the expectations and targets set by Company $\mathrm{S}$ during the past two or more years;

b. The suppliers deliver different kind of components which have a significant impact on the operational performance of Company S.

Supplier A is a European company producing slip ring units, which are one of the most critical outsourced subassemblies in Company S products. Design and production of main components are carried out in Europe, after which those components are shipped to China for other production activities. Customers, such as Company S, place orders through the main office in Europe.

Supplier B manufactures larger casted main components for Company S. The production process has two phases - casting and machining. These phases are carried out in separate sections within the same plant in China and shipped to Company S. The 
components are partly made-to-stock in the casting phase and made-to-order in the machining phase.

Supplier C is responsible for machining several key components. For this study, three most valuable components are considered. Supplier $\mathrm{C}$ ships components directly to Company S after the production. All components are made-to-order.

Supplier D delivers numerous types of hydraulic systems components such as hoses, couplings and connectors from its facilities in Northern Europe from where all orders are fulfilled and shipped to Company S in China. The hoses are made-to-order while the rest of the components are standard and directly shipped from the stock.

\section{Causes of delivery-time variance}

In this section, the causes for high delivery-time by the case suppliers are presented see table 1. Poor delivery performance by these suppliers to Company S typically disrupts its production plans in two ways. Firstly, since the production planning at Company $\mathrm{S}$ is scheduled based on the available production slots and delivery dates promised to the customer, delivering earlier than agreed is generally disadvantageous. This due to increased inventory levels and capital tie-downs.

Table 1. Summary of observations at the case companies

\begin{tabular}{lllll}
\hline & Supplier A & Supplier B & Supplier C & Supplier D \\
\hline $\begin{array}{l}\text { Primary } \\
\text { source of } \\
\text { untimely } \\
\text { delivery }\end{array}$ & $\begin{array}{l}\text { Poor coordination } \\
\text { between design } \\
\text { departments of Co. }\end{array}$ & $\begin{array}{l}\text { Defective output } \\
\text { from the casting } \\
\text { process }\end{array}$ & $\begin{array}{l}\text { Lack of process } \\
\text { standardization }\end{array}$ & $\begin{array}{l}\text { Long transport } \\
\text { time; inflexibility in } \\
\text { order fulfilment } \\
\text { process; }\end{array}$ \\
$\begin{array}{l}\text { Where/ } \\
\text { when } \\
\text { does it } \\
\text { happen? }\end{array}$ & $\begin{array}{l}\text { Design phase, due } \\
\text { to need for custom- } \\
\text { er and } \text { S }^{\text {rd party }}\end{array}$ & $\begin{array}{l}\text { Casting process } \\
\text { facility }\end{array}$ & $\begin{array}{l}\text { Entire operation } \\
\text { relating to this sup- } \\
\text { ply chain }\end{array}$ & Rush orders \\
$\begin{array}{l}\text { Other } \\
\text { observa- } \\
\text { tions }\end{array}$ & $\begin{array}{l}\text { Internal planning } \\
\text { and control prob- } \\
\text { lems leading to } \\
\text { missing parts }\end{array}$ & $\begin{array}{l}\text { Poor coordination } \\
\text { within the two sites; } \\
\text { high inventory after } \\
\text { casting process }\end{array}$ & $\begin{array}{l}\text { Need to have large } \\
\text { time buffers for } \\
\text { delivery of orders }\end{array}$ & $\begin{array}{l}\text { Internal planning } \\
\text { and control, leading } \\
\text { use of large buffers }\end{array}$ \\
\hline
\end{tabular}

Meanwhile, the second issue - of late deliveries from supplier - is adjudged by Company $\mathrm{S}$ to be of greater criticality. Such delays lead to production stoppages, waiting, overtime work, risk of high penalty and reputational damage from the shipyards. These then lead to increased costs in project execution and reduced profitability. To manage its own consequent order fulfillment process variability, which is relatively high, Company S uses internal buffers. 


\section{$5 \quad$ Discussion and Conclusions}

The purpose of this paper was to investigate the causes of delivery variance in a global, engineer-to-order maritime-equipment supply chain. Furthermore, we wanted to observe how those causes are managed in an empirical setting - the focal company of this study and four of its main suppliers. We found that the most significant causes for delays were poor communication and coordination at Supplier A, process inefficiency at Supplier B, lack of process standardization at Supplier C, and a long transport distance in addition to inflexibility in the order-fulfilment process at Supplier D. The lack of transparency in suppliers' order fulfillment process made it difficult for Company $\mathrm{S}$ to coordinate and manage suppliers. Very often, problems are discovered much later in the production process. As a result, it is highly problematic to trace the sequence of events that led to the issue precisely, and thus develop solutions to avoid such issues in the future. This is especially true with supplier A and B, who produce long lead-time components.

One reason for this is that process times are not measured at the suppliers, making it very difficult to trace the sources of process variability. Therefore, one key outcome of this study was the proposal that Company $\mathrm{S}$ and its suppliers begin to monitor actual process times or order fulfillment times, especially for orders involving long leadtime items. Another suggestion is to introduce delivery-time windows (or period) in purchase orders, thus allowing suppliers more flexibility in planning their own production to accommodate other operational constraints. In cultures where there is punishment for revealing issues, a management policy that rewards openness - maybe in the form of a continuous improvement programme - will lead to improvements.

Culture also plays a role - both within the focal company and at the suppliers. We observed that workers at the suppliers were afraid of being caught to have made mistakes, and for issues to be traced back to them. For the same reason, supplier development is also difficult because the local supply chain team (i.e., in Asia as opposed to Europe-based headquarters) of the focal company prefers that problems are not traceable. This way, those knotty issues can easily be ascribed (and this is often the case) to the differences between the European and Asian business environment.

Future research will extend the preliminary findings of this study by investigating how the use of penalties and rewards will work in this setting. In the next phase of this study, the use of a systematically determined penalty for untimely delivery from suppliers will be explored within this supply chain, as this is currently not in use. The penalty can be based on a revised and agreed delivery-time window, so that suppliers know the customer requirements, and are motivated to improve delivery-time performance. In the same vein, manufacturers such as Company S could also explore the possibility of rewarding suppliers who consistently exceed the performance targets either by publicizing this or by awarding a rank score which will influence future contract awards. 


\section{References}

1. McGovern, T., Hicks, C., Earl, C.F.: Modelling supply chain management processes in engineer-to-order companies. International Journal of Logistics: Research and Applications 2(2), 147-159 (1999).

2. Mello, M.H., Strandhagen, J.O.: Supply chain management in the shipbuilding industry: challenges and perspectives. Proceedings of the Institution of Mechanical Engineers, Part M: Journal of Engineering for the Maritime Environment 225(3), 261-270 (2011).

3. Milgate, M.: Supply chain complexity and delivery performance: an international exploratory study. Supply Chain Management: An International Journal 6(3), 106-118 (2001)

4. Gunasekaran, A., Patel, C., Tirtiroglu, E.: Performance measures and metrics in a supply chain environment. International journal of operations \& production Management 21(1/2), 71-87 (2001).

5. Bertrand, J., Muntslag, D.: Production control in engineer-to-order firms. International Journal of Production Economics 30(1), 3-22 (1993).

6. Hicks, C., McGovern, T., Earl, C.F.: Supply chain management: A strategic issue in engineer to order manufacturing. International Journal of Production Economics 65(2), 179190 (2000).

7. Caron, F., Fiore, A.: 'Engineer to order' companies: how to integrate manufacturing and innovative processes. International Journal of Project Management 13(5), 313-319 (1995).

8. Gosling, J., Naim, M.M.: Engineer-to-order supply chain management: A literature review and research agenda. International Journal of Production Economics 122(2), 741-754 (2009).

9. Assaf, S.A., Al-Hejji, S.: Causes of delay in large construction projects. International journal of project management 24(4), 349-357 (2006).

10. Mello, M.H., Strandhagen, J.O., Alfnes, E.: The role of coordination in avoiding project delays in an engineer-to-order supply chain. Journal of Manufacturing Technology Management 26(3), 429-454 (2015).

11. Zorzini, M., Corti, D., Pozzetti, A.: Due date (DD) quotation and capacity planning in make-to-order companies: Results from an empirical analysis. International Journal of Production Economics 112(2), 919-933 (2008).

12. Guiffrida, A.L., Jaber, M.Y.: Managerial and economic impacts of reducing delivery variance in the supply chain. Applied mathematical modelling 32(10), 2149-2161 (2008).

13. Guiffrida, A.L., Nagi, R.: Economics of managerial neglect in supply chain delivery performance. The Engineering Economist 51(1), 1-17 (2006). 